\title{
PENDAMPINGAN OPTIMALISASI MUTU KARET RAKYAT DI KABUPATEN SAROLANGUN
}

The Assistance Of Optimization Lateks Quality In Sarolangun District

\author{
Kiki Suheiti, Suharyon \\ Balai Pengkajian Teknologi Pertanian (BPTP) Jambi \\ JIn. Samarinda Paal V, Kotabaru, Jambi 36128 \\ e-mail: suheiti@gmail.com
}

\begin{abstract}
Latex has a big role in Indonesia's economic life. To increase the value added of smallholder latex products, which have improvements such as processing of latex as freezer and latex odor prevention. In this activity, a simple Batch type latek booster was assembled in Karet Sembawa Research Center. This tool is designed at an affordable price, simple and easy to apply for latex development projects. In addition, Deorub also tried as a freezer agent and latex odor prevention as a substitute for latex vinegar and Phospor fertilizer which has been used by local communities. With the Deorub application, the stench can be removed because Deorub contains of a composition that can be used as an antibacterial, antioxidant and as a latex freezer.
\end{abstract}

Keyword: latex, assistance, Sarolangun district

\begin{abstract}
Abstrak
Karet memiliki peranan yang besar dalam kehidupan perekonomian Indonesia. Untuk meningkatkan nilai tambah karet rakyat, salah satu upaya adalah melalui hasil olahan yang mempunyai prospek seperti pengolahan latek dadih (latek pekat yang diolah dengan pendadihan) dan penggunaan Deorub sebagai pembeku dan pencegah bau tak sedap padalateks. Pada pendampinan ini dicobakan sebuah alat pendadih latek sederhana tipe Batch yang dirakit di Balit Karet Sembawa. Alat ini dirancang dengan prinsip harganya yang relatif terjangkau oleh petani, proses pengolahan yang sederhana dan memungkinkan untuk diterapkan pada proyek pengembangan karet rakyat. Selain itu, dicobakan pula Deorub sebagai bahan pembeku dan pencegah bau tak sedap lateks sebagai pengganti cuka karet dan pupuk $P$ yang selama ini digunakan masyarakat setempat. Dengan aplikasi Deorub, bau busuk pada slab dapat dihilangkan karena Deorub mengandung senyawa-senyawa yang dapat berfungsi sebagai antibakteri, antioksidan dan sebagai pembeku lateks.
\end{abstract}

Katakunci : Karet alam, pendampingan, Kabupaten Sarolangun

\section{PENDAHULUAN}

Komoditas karet masih menjadi salah satu komoditas unggulan yang memegang peran penting dalam perekonomian masyarakat diProvinsi Jambi. Saat ini, kontribusi komoditas ini terhadap perolehan pendapatan daerah masih tergolong signifikan. Hal ini ditandai dengan kontribusinya terhadap Produk Domestik Regional Bruto (PDRB) yang masih relatif besar dibandingkan dengan komo- ditas pertanian lainnya. Data statistik menunjukkan bahwa komoditas karet berperan sebagai penyumbang devisa yang cukup besar terhadap perekonomian Provinsi Jambi. Pada tahun 2015 Provinsi Jambi tercatat mengekspor karet sejumlah 26.033,951 ton dengan nilai devisa sebesar US\$ 317.808 .535 (jambi. bps.go.id, 2015).

Berdasarkan wilayah sebarannya, komoditas karet dapat ditemui 
pada seluruh wilayah kabupaten/kota di Provinsi Jambi, kecuali Kota Jambi dan Kota Sungai Penuh, meskipun dengan tingkat kepadatan yang bervariasi. Luas tanaman karet di Provinsi Jambi sampai dengan tahun 2016 mencapai 663.981 hektar dengan produksi 333.168 ton (BPS, 2017).

Kendati demikian, kondisi karet rakyat masih menunjukkan gambaran yang memprihatinkan karena umumnya perkebunan karet rakyat masih kurang baik pada tahap pengolahannya. Hal ini tentu saja menyebabkan mutu karet olahan yang dihasilkan jauh dibawah standar yang berakibat harga jual karet tersebut rendah. Sementara itu, mutu karet olahan yang memenuhi standar dan memiliki harga jual tinggi dihasilkan oleh perkebunan-perkebunan besar milik pemerintah dan swasta. Petani sebagai pengusaha karet rakyat sebagian besar menjual hasil karetnya kepada pabrik pengolah karet alam dalam bentuk bekuan yang berwujud lump dan slab dengan harga rendah. Kemudian pihak pabrikan mengolah kembali dan menjual dalam betuk olahan dengan harga yang jauh lebih tinggi.

Untuk itu berbagai usaha untuk meningkatkan mutu karet rakyat yang dapat meningkatkan harga jual karet rakyat sangat diperlukan guna meningkatkan pendapatan petani karet. Salah satu wujud pendampingan yang dilakukan BPTP Jambi adalah dalam bentuk kegiatan teknologi pasca panen berbasis karet yaitu penggunaan Deorub sebagai pembeku dan pencegah bau busuk lateks dan alat pendadih lateks sederhana tipe Batch.

\section{TUJUAN PENELITIAN}

Melakukan pendampingan teknologi pasca panen berbasis karet dengan menggunanakan Deorub dan alat pendadih lateks di Desa Perdamaian, Singkut, Kabupaten Sarolangun, Provinsi Jambi, sehingga dapat meningkatkan kualitas mutu lateks.

\section{KAJIAN TEORI}

Sebagian besar bahan olahan karet (bokar) yang dihasilkan petani masih didominasi oleh jenis slab tebal dan ojol. Bokar dalam bentuk slab tebal merupakan hasil pengumpalan lateks yang dipanen dan dibekukan setiap hari. Kadar Karet Kering (KKK) jenis slab tebal umumnya berkisar antara 45-52 persen. Sedangkan bokar dalam bentuk ojol merupakan penggumpalan lump mangkok yaitu bekuan lateks yang dibiarkan 3-4 hari di setiap mangkok pada setiap batang. Kadar karet kering pada jenis ojol dapat mencapai 50-55 persen (Malian dan Jauhari, 1999).

Upaya perbaikan kualitas bokar selain didasarkan atas pertimbangan daya saing produk dipasar internasional, juga ditujukan untuk meningkatkan pendapatan petani. Suwardin, et al (2010), dalam penelitiannya tentang kualitas bokar dan pendapatan petani, mengatakan bahwa terbatasnya teknologi meru- 
pakan salah satu penyebab rendahnya kualitas bokar yang dihasilkan petani karet di Indonesia. Kualitas karet yang rendah pada gilirannya menyebabkan pendapatan yang diperoleh petani produsen menjadi rendah. Konsep pemikiran ini menyebabkan Suwardin menghipotesiskan bahwa introduksi teknologi pengolahan bokar kepada petani dapat meningkatkan penda-patan petani.

Lebih jauh, pengolahan lateks menjadi bahan baku karet alam seperti slab, crepe, sheet dan sebagainya masih dilakukan dengan sangat sederhana, sehingga mutu karet yang dihasilkan rendah. Mutu bahan olah karet sangat menentukan daya saing karet alam Indonesia di pasaran Internasional (Dinas Perkebunan Provinsi Jambi, 2007)

Lateks pekat merupakan produk olahan lateks alam yang dipekatkan dengan proses sentrifusi atau pendadihan dari Kadar Karet Kering (KKK) 28-30\% menjadi KKK $60-64 \%$. Biasanya lateks pekat digunakan untuk pembuatan bahanbahan karet yang tipis dan bermutu tinggi (Zuhra, 2006).

Pengolahan lateks pekat bertujuan untuk memperoleh Kadar Karet Kering (KKK) yang lebih tinggi, sehingga produk barang jadi karet mempunyai sifat yang lebih baik (Marsongko, 2013). Salah satu metode pengolahan lateks pekat dari lateks kebun yang dapat diterapkan di tingkat industri kecil atau petani adalah pengolahan lateks pekat dengan metode pendadihan. Metode ini dilakukan dengan cara mencampurkan bahan pendadih pada lateks kebun yang telah diawetkan dengan amonia, dan selanjutnya campuran tersebut dibiarkan mendadih selama waktu tertentu sampai mendapatkan lateks pekat yang dapat digunakan sebagai bahan baku industri barang jadi dari lateks.

Cara pendadihan tidak memerlukan peralatan yang mahal, sehingga pembuatan lateks pekat secara pendadihan sesuai untuk diterapkan industri kecil menengah (Triwijoso, 1989), salah satunya adalah pengolah karet busa. Hasil pengolahan lateks kebun dengan cara pendadihan ini diharapkan dapat mengurangi biaya produksi untuk industri kecil. Pada pendampingan ini dilakukan pengo-lahan lateks kebun menjadi lateks dadih menggunakan sebuah alat pendadih lateks sederhana yang dirakit dengan proses pengolahan sistem tumpuk (batch).

Sementara itu, dalam pengolahan lateks, salah satu tahap yang paling penting diperhatikan adalah tahap penggumpalan dengan menggunakan bahan penggumpal (koagulan). Penggunaan bahan penggumpal sangat berpengaruh terhadap mutu karet yang dihasilkan (Vachlepi, et al., 2015b). Petani karet di Provinsi Jambi biasanya menggunakan cuka karet, dan pupuk $P$ sebagai pembeku atau beku secara alami, kemudian slab disimpan selama satu sampai dua minggu bahkan satu bulan. Perlakuan ini menimbulkan bau busuk yang 
sangat menyengat pada slab. Bau busuk tersebut ditimbulkan oleh bakteri yang melakukan biodegradasi protein menjadi senyawa amonia dan sulfida. Disamping bau busuk, ternyata bakteri tersebut juga merusak antioksidan alami berupa protein dan asam amino didalam koagulum, serta penyebab lepasnya ion $\mathrm{Cu}++$ yang semula terikat oleh protein. Akibatnya, karet mudah teroksidasi pada saat dikeringkan yang ditunjukkan dengan rendahnya nilai PRI (Plasticity Retension Index) dari slab, terutama yang dibekukan secara alami (Solichin et al., 2003; Solichin et al.,2007).

Kedua hal tersebut terjadi karena bahan pembeku cuka karet, pupuk $\mathrm{P}$ dan beku alami tidak dapat mencegah bau busuk, karena pembeku tersebut tidak mengandung senyawa anti bakteri yang dapat mencegah pertumbuhan bakteri yang melakukan biodegradasi protein didalam slab, sehingga terjadi kerusakan antioksidan. Untuk mengatasi hal tersebut maka dapat digunakan formula asap cair yang berasal dari cangkang kelapa sawit yang disebut juga dengan Deorub sebagai pembeku. Asap cair merupakan suatu campuran larutan yang dibuat melalui proses kondensasi asap dari hasil pembakaran kayu (Oramahi, et al., 2010). Bahan baku pembuatan asap cair dapat bersumber dari limbah pertanian (Wahyudi, et al., 2014) dan berbagai jenis kayu seperti; kayu karet (Karseno, 2000), tempurung kelapa (Andayani, et al., 2014, Zuraida, et al., 2011)) dan kenari (Yusnaini, et al., 2012).

Deorub mengandung senyawasenyawa yang dapat berfungsi sebagai antibakteri (Achmadi, et al., 2013), antioksidan, pembeku, pemberi warna coklat dan bau asap yang khas (Karseno, et a.l., 2001; Solichin, 2004; Vachlepi et al., 2015a; Oramahi et al., 2013).

\section{METODE PENELITIAN \\ Penggunaan Deorub Sebagai Pembeku Dan Pencegah Bau Busuk Lateks}

Analisa mutu fisik dan spesifikasi teknis bekuan (slab) dilakukan di Laboratorium Balai Penelitian Sembawa. Bahan yang digunakan pada penelitian ini adalah lateks kebun dari perkebunan rakyat desa Perdamaian Singkut V, Deorub, cuka karet dan pupuk SP-36.

Perlakuan dalam penelitian ini adalah jenis bahan pembeku yang biasa digunakan petani dan bahan pembeku Deorub yang dikombinasikan dengan lama penyimpanan slab yang biasa dilakukan petani. Perlakuan tersebut meliputi:

1. Bahan Pembeku yang digunakan antara lain; Cuka Karet (teknologi petani),Pupuk SP-36 (teknologi petani), Tanpa bahan pembeku/beku alami (teknologi petani), Deorub (teknologi introduksi)

2. Lama Penyimpanan slab yang dicobakan adalah: 1 minggu, 2 minggu dan 1 bulan 
Adapun proses penggunaan masing-masing bahan pembeku lateks adalah sebagai berikut:

1. Cuka Karet

Cuka karet diencerkan terlebih dahulu dengan air dengan perbandingan 1:5. Lateks yang sudah penuh dalam mangkukmangkuk sadap dimasukkan kedalam wadah plastik yang volumenya 50 liter. Kemudian tambahkan cuka karet yang sudah diencerkan dan diaduk rata.

\section{Pupuk SP-36}

Pupuk $P$ langsung diberikan beberapa butir kedalam mangkuk sadap. Dosis atau takaran $10 \mathrm{gr}$ pupuk SP-36/l lateks.

3. Tanpa Bahan pembeku/Beku Alami

Lateks dibiarkan beku dengan sendirinya didalam mangkuk sadap, kemudian dicetak atau dilekatkan satu sama lainya sampai mempunyai berat sekitar 5-10 kg. Lama pembekuan cara alami 8 jam.

4. Deorub

Deorub pekat diencerkan terlebih dahulu menjadi Deorub 5\%, dengan mencampurkan satu bagian Deorub pekat dengan 19 bagian air bersih.

Larutan Deorub pekat berwarna coklat tua jernih, sedangkan Deorub $5 \%$ berwarna kuning Jernih.

Pemberian pada lateks adalah dengan mencampurkan 1 bagian Deorub 5\% dengan $10-12$ bagian lateks. Dengan demikian 1 liter asap cair Deorub pekat dapat membekukan 200 - 250 liter lateks atau setara $75 \mathrm{~kg}$ karet kering.

Pengamatan dilakukan terhadap parameter mutu yaitu: (1). Kondisi slab secara fisik yang meliputi lama pembekuan, tekstur, warna dan bau dan (2). Sifat spesifikasi teknis slab yang meliputi Kadar karet kering (KKK), Plastisitas awal (Po), Indeks ketahanan plastisitas (PRI), Kadar abu dan Kadar kotoran. Sedangkan untuk penilaian mutu bahan baku karet alam (slab) yang dihasilkan petani digunakan standar mutu slab yaitu Standar Mutu Skema SIR 2003, dengan spesifikasi teknis P0, PRI, kadar abu dan kadar kotoran.

Standar Mutu Skema SIR 2003 dapat dilihat pada Tabel 1

Tabel 1. Standar Mutu Skema SIR 2003

\begin{tabular}{lcl}
\hline Spesifikasi Teknis & SIR 10 & SIR 20 \\
\hline P0 & Min 30 & Min 30 \\
PRI & Min 50 & Min 60 \\
Kadar Kotoran (\%) & Maks 0.10 & Maks 0.20 \\
Kadar Abu (\%) & Maks 0.75 & Maks 1.00 \\
\hline \multicolumn{2}{c}{ Hasil penelitian membahas } & terhadap kondisi slab secara fisik \\
$\begin{array}{l}\text { karakteristik slab pada beberapa } \\
\text { jenis bahan pembeku, dan beberapa }\end{array}$ & $\begin{array}{l}\text { (lama pembekuan, tekstur, bau dan } \\
\text { tingkat lama penyimpanan, baik maupun spesifikasi teknis } \\
\text { slab (kadar karet kering (KKK), }\end{array}$
\end{tabular}


plastisitas awal (P0), indeks ketahanan plastisitas (PRI), kadar abu dan kadar kotoran.

\section{Alat Pendadih Lateks Sederhana Sistem Batch}

Alat dirancang dan dirakit di bengkel Balit Karet Sembawa Sumatera Selatan. Bahan dan alat yang digunakan adalah: drum Thermoplastik berkapasitas 120 liter dilengkapi dengan dua (2) kran PVC ukuran 0,5 inci, 1,5 $\mathrm{m}$ pipa PVC berdiameter 1,5 inci, dua (2) buah soket drat PVC, empat (4) buah klem jok dari besi, pengaduk yang terbuat dari plat aluminium $2,2 \mathrm{~mm}$ yang telah dilobangi dan tutup drum. Tangki ini mempunyai beberapa saluran yang antara lain berfungsi sebagai saluran penuangan, saluran pengeluaran lateks pekat, dan saluran pengeluaran serum, Kabupaten Sarolangun. Cara mengoperasikan alat pendadih latek:

a) Kumpulkan latek secepatnya, paling lambat 5 jam setelah penyadapan

b) Tuangkan latek melalui saringan 60 mesh ke dalam drum pengolahan melalui corong dibagian atas alat

c) Tambahkan bahan kimia secara berturut-turut; Larutan $20 \%$ amonia dengan dosis $50 \mathrm{ml} /$ liter latek kebun, Larutan $20 \%$ amonium laurat dosis 2,5 $\mathrm{ml} /$ liter latek kebun, Bahan pendadih larutan 2\% Ammonium alginate dengan dosis $0,20 \%$ atau larutan $2 \%$ CMC dengan dosis $0,25 \%$ berat kering bahan pendadih terhadap berat serum. (Berat serum adalah berat basah latek kebun dikurangi berat karet kering latek kebun yang diolah.)

d) Tutup ujung pipa pemasukan bahan untuk mengurangi kehilangan amonia selama pengadukan dan proses pendadihan.

e) Aduk secara merata campuran latek dan bahan kimia di dalam drum.

f) Serum yang dihasilkan, kemudian dikeluarkan keesokan harinya dari kran di bagian bawah drum

g) Proses tersebut diulang setiap hari sampai hari keempat belas, volume latek yang dimasukkan rata-rata 20 liter per hari

h) Hari kelima belas dan seterusnya akan dihasilkan dan dipanen latek pekat (dadih). Dari rata-rata $20 \mathrm{~kg}$ latek kebun per hari diperoleh latek pekat rata-rata $9,1 \mathrm{~kg}$ per hari.

\section{HASIL DAN PEMBAHASAN}

Penggunaan Deorub Sebagai

Pembeku Dan Pencegah Bau Busuk Lateks

1. Pengaruh Bahan Pembeku Dan Lama Penyimpanan Terhadap Kondisi Slab

Hasil pengujian dengan beberapa bahan pembeku lateks sangat berpengaruh terhadap kondisi slab secara fisik (tekstur, bau dan warna), sedangkan lama 
penyimpanan slab tidak mempe-

Hasil pengujian dapat dilihat Tabel 2. ngaruhi kondisi slab secara fisik.

Tabel 2.

Pengaruh beberapa bahan pembeku lateks dan lama penyimpanan terhadap karakteristik slab yang dihasilkan.

\begin{tabular}{|c|c|c|c|c|c|}
\hline \multirow{2}{*}{$\begin{array}{l}\text { Bahan } \\
\text { Pembeku }\end{array}$} & \multirow{2}{*}{$\begin{array}{c}\text { Waktu } \\
\text { pembekuan }\end{array}$} & \multirow{2}{*}{$\begin{array}{l}\text { Lama } \\
\text { Penyim } \\
\text { panan }\end{array}$} & \multicolumn{3}{|c|}{ Kondisi slab } \\
\hline & & & Tekstur & Bau & Warna \\
\hline \multirow{3}{*}{ Cuka karet } & \multirow{3}{*}{28 menit } & 1 minggu & Keras & busuk menyengat & Putih kotor \\
\hline & & 2 minggu & Keras & busuk menyengat & Putih kotor \\
\hline & & 1 bulan & Keras & busuk menyengat & Putih kotor \\
\hline \multirow{3}{*}{$\begin{array}{l}\text { Pupuk SP- } \\
36\end{array}$} & \multirow{3}{*}{55 menit } & 1 minggu & Keras & busuk menyengat & Putih kotor \\
\hline & & 2 minggu & Keras & busuk menyengat & Putih kotor \\
\hline & & 1 bulan & Keras & busuk menyengat & Putih kotor \\
\hline \multirow{3}{*}{ Beku Alam } & \multirow{3}{*}{24 jam } & 1 minggu & Keras & busuk menyengat & Putih kotor \\
\hline & & 2 minggu & Keras & busuk menyengat & Putih kotor \\
\hline & & 1 bulan & Keras & busuk & Putih kotor \\
\hline \multirow{3}{*}{ Deorub } & \multirow{3}{*}{10 menit } & 1 minggu & Keras & Bau asap & Permukaan coklat \\
\hline & & 2 minggu & Keras & Bau asap & Permukaan coklat \\
\hline & & 1 bulan & Keras & Bau asap & Permukaan coklat \\
\hline
\end{tabular}

Tabel 2. memperlihatkan bahwa bahan pembeku sangat berpengaruh terhadap kondisi slab yaitu kecepatan pembekuan, tekstur, bau, dan warna slab. Sedangkan lama penyimpanan slab tidak berpengaruh pada tekstur, bau dan warna slab. Pembeku Deorub dapat membekukan lateks hanya dalam waktu 10 menit. Hal ini disebabkan Deorub mengandung asam-asam terutama asam asetat yang dapat membekukan lateks dengan cepat, sesuai dengan yang dikemukakan
Solichin (2007) bahwa Deorub mengandung asam-asam terutama asam asetat yang berfungsi sebagai pembeku.

\section{Pengaruh bahan pembeku dan lama penyimpanan terhadap kadar karet kering slab (KKK).}

Hasil pengujian dengan beberapa bahan pembeku lateks dan lama penyimpanan sangat berpengaruh terhadap kadar karet kering (KKK) slab yang dihasilkan. Untuk lebih jelasnya dapat dilihat Tabel 3 .

Tabel 3.

Pengaruh bahan pembeku dan lama penyimpanan

terhadap kadar karet kering slab (\%)

\begin{tabular}{|c|c|c|c|}
\hline \multirow{2}{*}{ Bahan pembeku } & \multicolumn{3}{|c|}{ Lama Penyimpanan } \\
\cline { 2 - 4 } & 1 minggu & 2 minggu & 1 bulan \\
\hline Cuka karet & 30.37 & 58.84 & 70.16 \\
\hline Pupuk SP-36 & 32.56 & 59.43 & 72.79 \\
\hline Beku Alami & 35.09 & 60.28 & 74.81 \\
\hline Deorub & 56.21 & 79.33 & 87.92 \\
\hline
\end{tabular}

Hasil pengkajian menunjukkan penyimpanan sangat mempengaruhi

bahwa bahan pembeku dan lamanya kadar karet kering slab. Kadar karet 
kering meningkat dengan semakin lamanya penyimpanan, ini terjadi pada semua perlakuan jenis bahan pembeku dan tanpa pembeku, namun dengan semakin lamanya penyimpanan peningkatannya semakin kecil.

Dari Tabel 3. dapat dilihat bahwa slab yang dibekukan dengan Deorub mempunyai kadar karet kering paling tinggi dibandingkan dengan slab yang dibekukan dengan bahan pembeku lain pada semua tingkat lama penyimpanan. Hal ini disebabkan Deorub bersifat mempercepat pengeluaran air dari dalam slab atau tidak menahan air, yang ditunjukkan dengan kenaikan kadar karet kering yang semakin tinggi (Solichin et al., 2007).

Dampak dari sifat Deorub ini adalah bobot slab lebih ringan dibandingkan dengan slab yang dibekukan dengan pembeku lain, karena air dalam slab semakin habis karena tertarik keluar. Tetapi diimbangi oleh peningkatan kadar karet kering (KKK) yang lebih tinggi.

\section{Pengaruh bahan pembeku dan lama penyimpanan terhadap mutu spesifikasi teknis slab (Po, PRI, Kadar abu dan Kadar kotoran).}

Hasil pengujian dengan beberapa jenis bahan pembeku lateks dan lama penyimpanan sangat berpengaruh terhadap mutu spesifikasi teknis (P0, PRI, kadar abu dan kadar kotoran) slab. Untuk penilaian mutu bahan baku karet alam (slab) yang dihasilkan petani digunakan standar mutu slabyaitu Standar Mutu Skema SIR 2003, dengan spesifikasi teknis P0, PRI, kadar abu dan kadar kotoran. Untuk lebih jelasnya dapat dilihat Tabel 4 dan 5.

Tabel 4.

Pengaruh bahan pembeku dan lama penyimpanan terhadap plastisitas awal (P0) dan indeks ketahanan plastisitas (PRI)(\%).

\begin{tabular}{|c|c|c|c|c|c|c|}
\hline \multirow[t]{3}{*}{ Bahan pembeku } & \multicolumn{6}{|c|}{ Lama Penyimpanan } \\
\hline & \multicolumn{2}{|c|}{1 mingqu } & \multicolumn{2}{|c|}{2 minggu } & \multicolumn{2}{|c|}{1 bulan } \\
\hline & P0 & PRI & P0 & PRI & P0 & PRI \\
\hline Cuka karet & 32 & 45 & 37 & 45 & 30 & 43 \\
\hline Pupuk SP-36 & 29 & 40 & 33 & 46 & 26 & 48 \\
\hline Beku Alami & 34 & 38 & 35 & 37 & 32 & 40 \\
\hline Deorub & 57 & 58 & 54 & 53 & 53 & 72 \\
\hline $\begin{array}{l}\text { Standar Mutu Skema SIR } \\
2003 \text { (SIR 10) }\end{array}$ & Min 30 & Min 50 & Min 30 & Min 50 & Min 30 & Min 50 \\
\hline $\begin{array}{l}\text { Standar Mutu Skema SIR } \\
2003 \text { (SIR 20) }\end{array}$ & Min 30 & Min 60 & Min 30 & Min 60 & Min 30 & Min 60 \\
\hline $\begin{array}{l}\text { P0 dan PRI } \\
\text { komponen mutu dari } \\
\text { semakin tinggi nilai } \\
\text { semakin tinggi kualitas } \\
\text { memperlihatkan bahw }\end{array}$ & $\begin{array}{l}\text { mer } \\
\text { slab } \\
\text { P0 da } \\
\text { slab. } \\
\text { a slab }\end{array}$ & $\begin{array}{l}\text { Ipakan } \\
\text { limana } \\
\text { PRI } \\
\text { abel } 4 \\
\text { engan }\end{array}$ & $\begin{array}{l}\text { pemk } \\
\text { dan } \\
\text { dingk } \\
\text { diduc } \\
\text { mens }\end{array}$ & $\begin{array}{l}\text { U Dec } \\
\text { RI jaur } \\
\text { deng } \\
\text { karen } \\
\text { dung }\end{array}$ & $\begin{array}{l}\text { Ib mer } \\
\text { lebih } t \\
\text { slab } \\
\text { asap } \\
\text { senya }\end{array}$ & $\begin{array}{l}\text { nyai } P \\
\text { i dibar } \\
\text { hal ir } \\
\text { Deoru }\end{array}$ \\
\hline
\end{tabular}


anti-oksidan (fenol dan turunannya) yang dapat menahan oksidasi molekul-molekul karet, sehingga PO (panjangnya rantai molekul karet atau berat molekul) dan PRI (Ketahanan molekul karet terhadap oksidasi suhu tinggi) tetap tinggi.

Tabel 5.

Pengaruh bahan pembeku dan lama penyimpanan terhadap kadar abu (\%) dan kadar kotoran (\%).

\begin{tabular}{|c|c|c|c|c|c|c|}
\hline \multirow{3}{*}{ Bahan pembeku } & \multicolumn{6}{|c|}{ Lama Penyimpanan } \\
\hline & \multicolumn{2}{|c|}{1 minggu } & \multicolumn{2}{|c|}{2 minggu } & \multicolumn{2}{|c|}{1 bulan } \\
\hline & $\begin{array}{l}\text { Kadar } \\
\text { Abu } \\
(\%)\end{array}$ & $\begin{array}{l}\text { Kadar } \\
\text { Kotoran } \\
(\%)\end{array}$ & $\begin{array}{l}\text { Kadar } \\
\text { Abu } \\
(\%)\end{array}$ & $\begin{array}{l}\text { Kadar } \\
\text { Kotoran } \\
(\%)\end{array}$ & $\begin{array}{c}\text { Kadar } \\
\text { Abu (\%) }\end{array}$ & $\begin{array}{l}\text { Kadar } \\
\text { Kotoran }\end{array}$ \\
\hline Cuka karet & 1.02 & 0.21 & 1.13 & 0.24 & 1.56 & 0.28 \\
\hline Pupuk SP-36 & 0.56 & 0.22 & 0.69 & 0.11 & 0.78 & 0.26 \\
\hline Beku Alami & 0.46 & 0.16 & 0.48 & 0.12 & 0.48 & 0.21 \\
\hline Deorub & 0.27 & 0.09 & 0.24 & 0.09 & 0.45 & 0.10 \\
\hline $\begin{array}{c}\text { Standar Mutu } \\
\text { Skema SIR } 2003 \\
\text { (SIR 10) }\end{array}$ & $\begin{array}{l}\text { Mak/M } \\
\text { ax } 0.75\end{array}$ & $\begin{array}{c}\text { Mak /Max } \\
0.10\end{array}$ & $\begin{array}{c}\text { MakMa } \\
\times 0.75\end{array}$ & $\begin{array}{c}\text { Mak/Max } \\
0.10\end{array}$ & $\begin{array}{c}\mathrm{Mak} / \mathrm{Ma} \\
\text { x } 0.75\end{array}$ & $\begin{array}{c}\mathrm{Mak} / \mathrm{Max} \\
0.10\end{array}$ \\
\hline $\begin{array}{c}\text { Standar Mutu } \\
\text { Skema SIR } 2003 \\
(\text { SIR 20) }\end{array}$ & $\begin{array}{l}\text { Mak/M } \\
\text { ax } 1.00\end{array}$ & $\begin{array}{c}\text { Mak/Max } \\
0.20\end{array}$ & $\begin{array}{l}\text { Mak/M } \\
\text { ax } 1.00\end{array}$ & $\begin{array}{c}\text { Ma/Maxk } \\
0.20\end{array}$ & $\begin{array}{c}\mathrm{Mak} / \mathrm{Ma} \\
\times 1.00\end{array}$ & $\begin{array}{c}\text { Mak/Max } \\
0.20\end{array}$ \\
\hline
\end{tabular}

Kadar abu dan kadar kotoran dari bekuan sangat dipengaruhi oleh proses pengolahan yang dilakukan petani dalam pembuatan slab seperti penambahan bahan-bahan pengisi kedalam karet pada waktu pengolahan (Setyamidjaya, 2000). Kebiasaan petani karet mencampur slab dengan kotoran dan bahan ikutan lainya sangat mempengaruhi kadar abu dan kadar kotoran. Dalam penelitian ini dapat dilihat bahwa kadar abu dan kadar kotoran dari slab yang dibekukan oleh petani dengan cuka karet, pupuk $\mathrm{P}$ dan beku alami cukup tinggi tidak memenuhi persyaratan mutu Skema SIR 10 dan 20, yaitu kadar kotoran maksimal $0.10 \%$ untuk SIR 10 dan $0.20 \%$ untuk SIR 20, sedangkan kadar abu $0.75 \%$ untuk SIR 10 dan $1.0 \%$ untuk SIR 20. Hasil penelitian menunjukkan bahwa

pembekuan lateks dengan asap cair Deorub memiliki mutu yang memenuhi syarat spesifikasi teknis SIR 10 dan SIR 20 (Skema SIR 2003), dibandingkan dengan pem-beku yang biasa digunakan petani.

Penggunaan Deorub sebagai bahan pembeku dapat membekukan lateks lebih cepat yaitu 10 menit, sedangkan cuka karet 28 menit dan pupuk SP-36 55 menit. Selain itu, Deorub yang digunakan sebagai pembeku dapat mencegah bau busuk slab karena mengandung senyawa anti bakteri. Slab yang dibekukan dengan Deorub mempunyai kadar karet kering paling tinggi yaitu $87.92 \%$, sedangkan pembeku cuka karet $70.16 \%$ dan pupuk SP-36 $72.79 \%$ selama penyimpanan 1 bulan. Lebih jauh, Slab yang dibekukan dengan Deorub 
mempunyai kualitas yang memenuhi syarat spesifikasi teknis SIR 10 dan SIR 20 dibanding dengan pembeku yang biasa digunakan petani (cuka karet dan pupuk SP-36). Harga relatif sama dengan pembeku lain. Lebih jauh, bekuan tidak berbau busuk dan ramah lingkungan.

\section{ALAT PENDADIH LATEKS SEDERHANA SISTEM BATCH}

\section{Tabel 6.}

Hasil Lateks Dadih dan Serum dengan Menggunakan Alat Pendadih Lateks Sederhana.

\begin{tabular}{clcc}
\hline No. & Pengamatan & Lateks Dadih & Serum \\
\hline 1. & Bobot (I) & 33.64 & 38.22 \\
2. & KKK $(\%)$ & 55.45 & 6.36 \\
\hline
\end{tabular}

Dari Tabel 6. dapat dilihat, lateks dadih yang dihasilkan setelah dilakukan pemisahan serum pada hari ke 15 (lima belas) berjumlah 33.64 liter dan mempunyai KKK $55.45 \%$ dengan bahan pendadih Carboksil Metyl Cellulose (CMC). Sedangkan serum berjumlah 38.22 liter dan mempunyai KKK 6.36\%. Terdapatnya bahan pendadih menyebabkan terjadinya aglomerasi pada butir-butir karet yang memiliki diameter-diameter besar, perbedaan berat jenis butir karet dan serum juga terjadi, yang akan mempercepat gerakan partikel karet naik kepermukaan sehingga butir-butir karet akan mengelompok dipermukaan (Noble, 1953).
Demikian juga yang dikatakan Blackley (1966), lateks kebun yang telah diawetkan dengan amonia, dan ditambahkan bahan pendadih, kemudian diaduk selama $1 / 2$ sampai 1 jam dan didiamkan selama 40 jam, selama waktu tersebut proses pendadihan sudah mulai berjalan sampai selesai, serum akan turun ke bawah dan lateks pekat akan naik keatas.

Hasil analisa mutu lateks dadih dengan sistem Batch yang dihasilkan dengan alat sederhana rakitan Balit Sembawa, setelah disimpan selama 14 hari di perkebunan karet rakyat Desa Perdamaian Singkut V Kecamatan Singkut Kabupaten Sarolangun dapat dilihat pada Tabel 7.

Tabel 7.

Hasil Pengujian Mutu Lateks Dadih yang Dihasilkan Petani

\begin{tabular}{|c|l|c|l|}
\hline No. & \multicolumn{1}{|c|}{ Komponen Mutu } & Hasil & \multicolumn{1}{c|}{ ISO 2004 } \\
\hline 1. & Kadar Karet Kering (\%) & 55,45 & $64(\mathrm{~min})$ \\
\hline 2. & pH & 10,80 & $10,80-11,80$ \\
\hline 3. & Kadar Non Karet $(\%)$ & 3,30 & $2,00(\mathrm{mak})$ \\
\hline 4. & Kadar Jumlah Padatan (\%) & 58,76 & $66(\mathrm{~min})$ \\
\hline 5. & Warna & Putih & $\begin{array}{l}\text { Tidak kebiru-biruan/ abu- } \\
\text { abu }\end{array}$ \\
\hline 6. & Bau & Tidak berbau besi & Tidak berbau besi \\
\hline
\end{tabular}

Dari Tabel 7. dapat dilihat sederhana, belum mampu memebahwa lateks dadih yang dihasilkan nuhi standar mutu lateks dadih ISO secara sistem Batch dengan alat 2004. Kadar Karet Kering (KKK) 
yang dihasilkan adalah $55.45 \%$, jauh dibawah standar KKK ISO 2004 yaitu minimum 64\%. Demikian juga halnya dengan Kadar Non Karet (KNK) yang dihasilkan masih terlalu tinggi yaitu $3.30 \%$, sedangkan menurut standar mutu ISO 2004 KNK maksimum adalah 2.00\%. Untuk Kadar Jumlah Padatan (KJP) ISO 2004 adalah minimum $66 \%$, sedangkan hasil yang didapat hanya $58.76 \%$. Namun,pH sudah menunjukkan memenuhi standar mutu dimana $\mathrm{pH}$ lateks dadih yang terbaik adalah berkisar 10.8 -11.8. Sama halnya padakomponen warna dan bau lateks dadih yang dihasilkan sudah memenuhi standar mutu ISO 2004 yaitu berwarna putih dan tidak berbau besi.

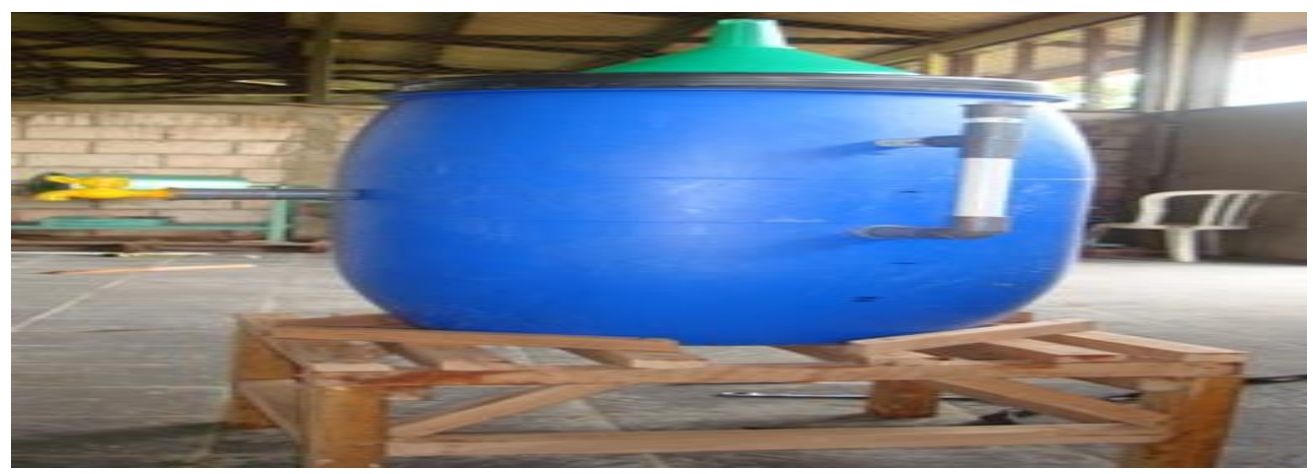

Gambar 1. Alat pendadih lateks sederhana tipe Batch

Banyak faktor yang mempengaruhi mutu hasil pengolahan lateks dadih, menurut Noble (1953) faktor-faktor yang mempengaruhi proses pendadihan adalah jumlah dan jenis bahan pendadih, umur lateks, suhu, $\mathrm{pH}$ lateks, pengadukan, dan viskositas lateks. Pengadukan yang sempurna merata pada lateks akan sangat diharapkan pada proses pendadihan. Hal ini dapat memperpendek periode induksi serta dapat meningkatkan kepekatan lateks dadih. Pada pengkajian ini pengadukan dilakukan secara manual dan bergantian antara petani sehingga kecepatan, kekuatan dan kesempurnaan pengadukan sangat tergantung pada kecepatan tangan petani.

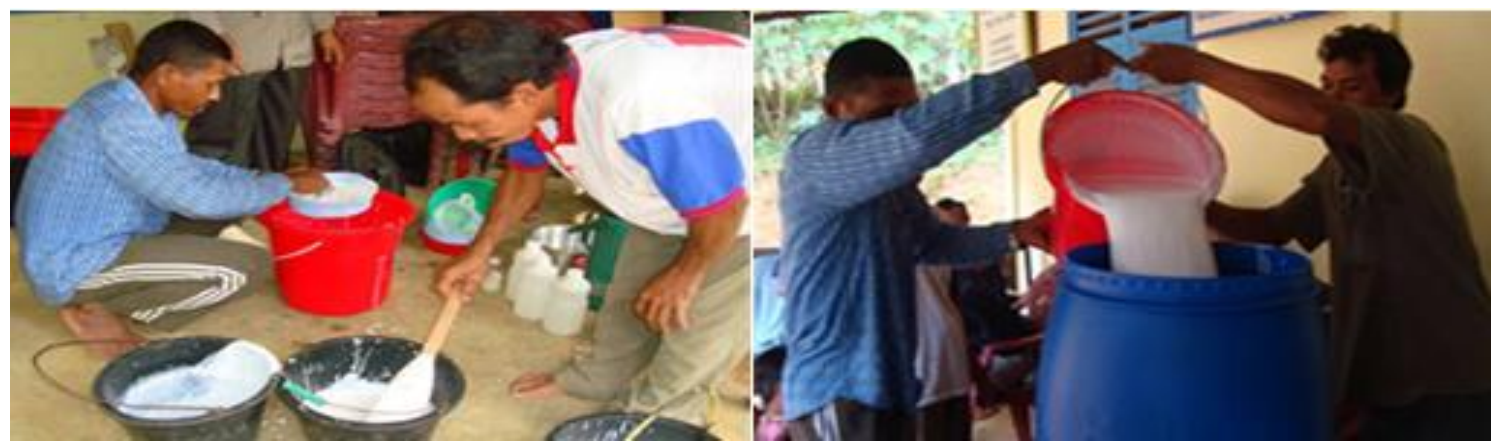

Gambar 2. Proses pendadihan ateks

PENUTUP

Berdasarkan hasil penerapan teknologi penggunaan Deorub sebagai bahan pembeku, dapat membekukan lateks lebih cepat yaitu dalam waktu hanya 10 menit, 
sedangkan menggunakan cuka karet dan puuk SP-36, memakan waktu 28 menit dan 55 menit berturut-turut Deorub yang digunakan sebagai pembeku dapat mencegah bau busuk slab karena mengandung senyawa anti bakteri. Sementara itu, penggunaan alat pendadih lateks sederhana di wilayah pendampingan karet di Sarolangun, menghasilkan kualitas latek yang masih belum memenuhi semua persyaratan standar mutu lateks 2004. Hal ini karena system pengadukan yang masih dilakukan secara manual dan bergantian antar petani sehingga terdapat ketidak konsistensian terhadap kecepatan, kekuatan dan kesempurnaan penga-dukan. Masih dibutuhkan penyempurnaan desain alat pendadih sehingga dapat memperbaiki faktor mutu lateks.

\section{DAFTAR PUSTAKA}

Achmadi SS, Mubarik NR, Nursyamsi R and Septiaji P. 2013. Characterization of redistilled liquid smoke of oilpalm shells and its application as fish preservatives. Journal of Applied Sciences. Vol 13(3):401-408. doi:10.3923/jas.2013.401-408. (diunduh tanggal 5 Agustus 2016).

Andayani, R, S.Wijana dan A.F. Mulyadi. 2014. Analisis Kela yakan Teknis dan Finansial

Biro Pusat Statistik (BPS). 2017. Statistik Perkebunan Provinsi Jambi. Biro Pusat Statistik, Jambi.

Biro Pusat Statistik (BPS). 2010. Statistik Perkebunan Provinsi
Jambi. Biro Pusat Statistik, Jambi.

Blackley, D.C.1966. High Polymer Latices. Palerton Publishing Co. Inc, New York.

Dinas Perkebunan Provinsi Jambi. 2007. Profil Potensi Pengolahan Hasil Komoditas Unggulan Perkebunan Provinsi Jambi.

https://jambi.bps.go.id/dynamictable/ 2018/05/28/450/volume-dannilai-ekspor-komoditi-perke bunan-provinsi-jambi-19992015-.html Diakses 8 Oktober 2018.

Karseno. 2000. Antibakteri asap cair kayu karet (Hevea brasiliensis) dan spektrum pengham batannya. Tesis S2 Program Studi IImu Dan Teknologi Pangan, Jurusan IImu IImu Pertanian. Program Pasca Sarjana Universitas Gajah Mada,Yogyakarta.

Karseno, Darmaji $\mathrm{P}$ dan Kapti R. 2001. Daya Hambat Asap Cair Kayu Karet Terhadap Bakteri Pengkontaminan Lateks dan Ribbed Smoke Sheet. Agritech 21 (1): $10-15$.

Marsongko. (2013). Pembuatan Sarung Tangan dari Lateks Alam yang Divulkanisasi Radiasi dan Belerang. Jurnal Kimia Kemasan Vol. 35 Tahun 2013, Hal. 131-140

Noble, R. J. 1953. Latex in Industry. Rubber age, New York.

Oramahi, H.A, Farah, D dan Wahdina. 2010. Efikasi Asap Cair dari tandan Kosong Kelapa Sawit (TKKS) Dalam Penekanan Perkembangan Jamur Aspergilus Niger.J.HPT Tropika.10 (2): 146 - 153.

Oramahi H.A and Diba F. 2013.Maximazing Teh 
Production of Liquid Smoke from Bark of Durio by Studying its Potential Compaounds. Procedia Environ. Sci. 17: 60 69.

Pendirian Unit Pengolahan Limbah Tempururng Kelapa (Asap cair dan karbon Aktif).Thesis S2 Jurusan Teknologi Industri Pertanian - FTP. Universitas Brawijaya. Malang.

Solichin, M dan Anwar. 2003. Pengaruh Penggumpalan Lateks, Perendaman dan Penyemptotan Bokar Dengan Asap Cair Terhadap Bau Bokar, Sifat Teknis, Dan Sifat Fisik Vulkanisat. Jurnal Penelitian Karet. Vol. 21(1-3).

Solichin, M, A.N. A. Tedjaputra. Penggunaan Asap Cair Deorub Dalam Pengolahan RSS. 2007. Jurnal Penelitian Karet. 25 (1): 83-94

Suwardin,D., H.M.Solichin., R.Raswil., A.M. Satosa, dan A.Anwar. Pengolahan Bahan Olah karet. 2010. Balai Penelitian Sembawa, Pusat Penelitian Karet.

Triwijoso, S.U. (1989). Pedoman Teknis Pengawetan Lateks Hevea. Balai Penelitian Perkebunan Bogor. Bogor

Vachlepi, A, D.Suwardin dan M. Purbaya. 2015b. Karakterisasi Kondisi Penggumpalan dan Mutu Karet yang Digumpalkan dengan Koagulan Deorub Formula Baru. Jurnal Penelitian Karet. 33 (2): $175-182$.

Vachlepi, A and D. Suwardin. 2015a. Characterization of Iron Metal Corrosion in Liquid Smoke Coagulant.

Prosedia

Chemsitry.16: $420-426$.

Wahyudi, D., Kurnia, R, Edl S and Anwar K. 2014. Principle
Component Analysis(PCA) of Selected Liquid Smoke by Product. Journal of Chemical and

Pharmaceutical

Reasearch. 6 (11): 239 -242. http//www.jocpr.com. (diunduh tanggal 5 Agustus 2016).

Yusnaini, Soeparno, E. Suryanto and R. Armunanto. 2012. Physical, Chemical and Sensory Properties of Kenari (Canarium Indocum L) Shell liquid Smoke - Immersed - Beef on Different Level of Dillution. http://ejournal.undip.ac.id/index. php/jitaa/article. (diunduh Tanggal 3 Agustus 2015).

Zuhra, Cut Fatima. 2006. Karet. Karya Tulis IImiah. Departemen Kimia Fakultas Matematika dan Ilmu Pengetahuan Alam. Universitas Sumatera Utara. Medan

Zuraida, I., Sukarno and S. Budijanto. 2011. Antibacterial activity of coconut shell liquid smoke (CSLS) and its application on fish ball preservation. Int. Food. Res. J.18: 405-410. 